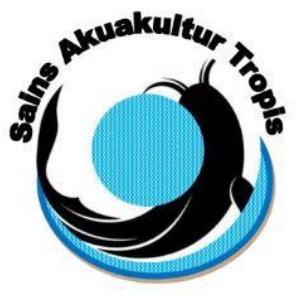

\author{
Jurnal Sains Akuakultur Tropis \\ De p a r e m e n A u a k I t u r \\ Fakultas Perikanan dan IImu Kelautan - Universitas Diponegoro \\ JI. Prof. Soedarto, SH, Tembalang, Semarang 50275 \\ Telp. (024) 7474698, Fax.: (024) 7474698 \\ Email: sainsakuakulturtropis@gmail.com, sainsakuakulturtropis@undip.ac.id
}

\title{
PENGARUH JARAK TANAM RUMPUT LAUT (Sargassum sp.) YANG BERBEDA TERHADAP PERTUMBUHAN
}

Effect of Different Spacing of Seaweed (Sargassum sp.) on Growth

\section{Muhamad Ichwanul Fajri, Istiyanto Samidjan), Diana Rachmawati}

Departemen Akuakultur, Fakultas Perikanan dan Ilmu Kelautan, Universitas Diponegoro

J1. Prof. Soedarto, SH, Tembalang, Semarang, Jawa Tengah-50275, Telp/Fax. +62247474698

* Corresponding author: istiyanto_samidjan@yahoo.com

\begin{abstract}
ABSTRAK
Rumput laut termasuk dalam golongan alga yaitu kelompok tumbuhan yang mempunyai klorofil, terdiri dari satu atau banyak sel, berbentuk koloni. Sargassum sp. merupakan alga coklat yang paling melimpah di perairan tropis. Penelitian ini bertujuan untuk mengetahui pengaruh jarak tanam dan menentukan jarak tanam terbaik untuk pertumbuhan rumput laut Sargassum sp. di balai perbenihan ikan air payau dan laut tugu, kota semarang. Rumput laut (Sargassum sp.) uji yang digunakan dengan bobot $50 \mathrm{~g}$. Metode yang digunakan pada penelitian ini yaitu dengan menggunakan metode eksperimental menggunakan rancangan acak lengkap (RAL) dengan 3 perlakuan dan 3 kali ulangan. Perlakuan A, B, dan C adalah jarak tanam dengan masing-masing sebesar $23 \mathrm{~cm}, 28 \mathrm{~cm}, 33 \mathrm{~cm}$. Variabel yang diamati meliputi laju pertumbuhan relatif (RGR) dan kualitas air. Hasil penelitian menunjukan bahwa jarak tanam Sargassum sp. yang berbeda memberikan pengaruh sangat nyata $(\mathrm{P}<0,01)$ terhadap RGR. Perlakuan $\mathrm{C}$ (jarak tanam 33 $\mathrm{cm}$ ) menghasilkan nilai tertinggi pada RGR rumput laut Sargassum sp. sebesar 0,82 $\pm 0,12 \%$ /hari, perlakuan B (jarak tanam $28 \mathrm{~cm}$ ) didapatkan hasil $0.64 \pm 0.04 \% /$ hari, perlakuan A (jarak tanam $23 \mathrm{~cm}$ ) didapatkan hasil $0.54 \pm 0.06 \% /$ hari dan parameter kualitas air selama penelitian didapatkan hasil kisaran suhu $25-34,1^{\circ} \mathrm{C}$, pH berkisar antara $7,12-8,20$, salinitas berkisar antara 10-21 ppt. Kesimpulan dari penelitian ini yaitu jarak tanam terbaik terhadap laju pertumbuhan relatif rumput laut yaitu pada jarak tanam $33 \mathrm{~cm}$, adanya pengaruh sangat nyata $(\mathrm{P}<0,01)$ dari perbedaan jarak tanam terhadap laju pertumbuhan relative. Saran dari penelitian ini yaitu perlu adanya kualitas air yang layak supaya rumput laut dapat hidup selama budidaya.
\end{abstract}

Kata kunci: Sargassum, pertumbuhan, pengaruh

\section{ABSTRACT}

Seaweed belongs to the algae group, which is a group of plants that have chlorophyll, consisting of one or many cells, in the form of a colony. Sargassum sp. is the most abundant brown algae in tropical waters. This research aims to determine the effect of different spacing and determine the best spacing for the growth of seaweed Sargassum sp. in the brackish and sea water fish seedling center Tugu, Semarang city. Seaweed Sargassum sp. test used with a weight of 50 g. The method used in this study is to use an experimental method using a completely randomized design (CRD) with 3 treatments and 3 replications. The treatments $A, B$, and C are spacing with $23 \mathrm{~cm}, 28 \mathrm{~cm}, 33 \mathrm{~cm}$, respectively. Variables observed include relative growth rate $(R G R)$ and water quality. The results showed that the spacing of Sargassum sp. different effect very significantly $(P<0.01)$ on RGR. Treatment $C$ (plant spacing of $33 \mathrm{~cm}$ ) produced the highest value on RGR of Sargassum sp. amounted to $0.82 \pm 0.12 \%$ / day, B treatment (spacing of $28 \mathrm{~cm}$ ) showed $0.64 \pm 0.04 \%$ / day, A treatment (planting distance of $23 \mathrm{~cm}$ ) showed $0.54 \pm 0.06 \%$ / day and water quality parameters during the study obtained a temperature range of $25-34.1^{\circ} \mathrm{C}, \mathrm{pH}$ ranged from 7.12 to 8.20 , salinity ranged from $10-21$ ppt. The 
conclusion of this research is the best planting distance to the relative growth rate of seaweed that is at a distance of 33 $\mathrm{cm}$, there is a very real effect of the difference in spacing on the relative growth rate. Suggestion from this research is the need for adequate water quality so that seaweed can live during cultivation.

Keywords: Sargassum sp., spacing, growth.

\section{PENDAHULUAN}

Rumput laut merupakan salah satu komoditi unggulan dalam perdagangan dunia, Indonesia merupakan salah satu negara yang menjadi penyuplai bahan baku rumput laut bagi negara yang membutuhkan. Tingkat ekspor Indonesia dalam hal rumput laut yakni naik turun sepanjang tahun 2015-2017. Menurut Kementrian Kelautan dan Perikanan (2018), tingkat ekspor rumput laut Indonesia pada tahun 2015 mencapai 212 ribu ton, tahun 2016 turun menjadi 188 ribu ton, tahun 2017 meningkat menjadi 192 ribu ton. Sargassum sp. merupakan jenis rumput laut paling melimpah dari kelompok alga coklat (Phaeophyceae) yang tersebar di perairan tropis, termasuk di Indonesia. Lingkungan tempat tumbuh Sargassum sp. banyak terdapat di daerah perairan yang jernih dengan substrat dasar batu karang, karang mati, batuan vulkanik, dan benda-benda yang bersifat massive yang berada di dasar perairan. Sargassum sp. tumbuh di daerah intertidal, subtidal, sampai daerah tubir dengan ombak. Kedalaman untuk pertumbuhan dari 0,5-10 m. Sargassum sp. dapat tumbuh sepanjang tahun, bersifat perenial atau setiap musim barat maupun timur dapat dijumpai di berbagai perairan (Muslimin dan Sari, 2017). Menurut Kadi (2005) dalam Pakidi dan Suwoyo (2016), Sargassumm sp. mengandung bahan alginat dan iodin yang digunakan pada industri makanan, farmasi, kosmetik dan tekstil. Selain itu, Sargassum sp. mengandung senyawa-senyawa aktif steroida, alkoloida, fenol, dan trirterpenoid berfungsi sebagai anti bakteri, antivirus, dan anti jamur (Kusumaningrum et al. 2007). Jarak tanam rumput laut berfungsi untuk peningkatan produksi rumput laut. Menurut Aditia dan Ilham (2015), perbedaan jarak tanam dalam budidaya rumput laut memiliki fungsi untuk mengetahui berapa jarak antar tanaman yang paling tepat sehinga pertumbuhan lebih optimum. Pongarrang et al. (2013), perbedaan jarak tanam sangat berpengaruh terhadap pertumbuhan rumput laut. Hal ini sangat berkaitan dengan persaingan setiap individu rumput laut dalam mendapatkan unsur hara sebagai makanannya. Jarak tanam merupakan salah satu faktor teknis yang berpengaruh terhadap pertumbuhan rumput laut karena hubungannya dengan penyerapan unsur hara yang salin berkaitan. Penelitian ini bertujuan untuk mengetahui pertumbuhan rumput laut dengan jarak tanam Sargassum sp. yang berbeda dan mengetahui pertumbuhan terbaik pada rumput laut Sargassum sp. dengan jarak tanam yang berbeda. Penelitian ini dilaksanakan pada bulan April 2019 di Balai Perbenihan Ikan Air Payau dan Laut Karanganyar, Kecamatan Tugu Kota Semarang.

\section{MATERI DAN METODE}

Alat yang digunakan dalam penelitian ini meliputi bambu, tali poliethylen $0,10 \mathrm{~mm}$, gergaji kayu, palu, besek, timbangan digital, water quality control (WQC).

Kultivan yang digunakan bibit rumput laut Sargassum sp didapatkan dari pembudidaya di Kalianda, Lampung dengan bobot masing- masing perlakuan 50g. (Herliany et al. 2016).

Metode penelitian yang digunakan dalam penelitian ini adalah eksperimental dan menggunakan rancangan acak lengkap (RAL) dengan 3 perlakuan dan 3 pengulangan modifikasi dari metode penelitian yang dilakukan (Herliany et al. 2016) jarak tanam rumput laut yang berbeda. Perlakuan yang dilakukan dalam penelitian ini adalah sebagai berikut:

Perlakuan tersebut sebagai berikut :

Perlakuan A : jarak tanam rumput laut $23 \mathrm{~cm}$

Perlakuan B : jarak tanam rumput laut $28 \mathrm{~cm}$

Perlakuan C : jarak tanam rumput laut $33 \mathrm{~cm}$

\section{Pengumpulan Data}

Variabel yang diukur pada penelitian ini meliputi laju pertumbuhan relatif rumput laut dan kualitas air. Data kualitas air yang diukur meliputi DO, suhu, $\mathrm{pH}$, dan salinitas yang diukur setiap hari selama penelitian, serta nitrat, nitrit, fosfat dan ammonia awal dan akhir penelitian di Laboratorium.

1. Laju pertumbuhan relatif (RGR)

Laju pertumbuhan relatif (Relative Growth Rate) kultivan dihitung dengan menggunakan rumus (Takeuci, 1998), yaitu :

$$
R G R=\frac{W t-W o}{W n \times t} \times 100 \%
$$

Dimana : RGR = laju pertumbuhan relatif (\%/hari)

$\mathrm{W}_{\mathrm{t}} \quad=$ bobot kultivan pada akhir pemeliharaan $(\mathrm{g})$ 
2. Kualitas air

$\mathrm{W}_{\mathrm{o}} \quad=$ bobot kultivan pada awal pemeliharaan $(\mathrm{g})$

$\mathrm{t} \quad=$ lama pemeliharaan (hari)

Kualitas air yang diukur setiap hari selama penelitian dengan menggunakan DO meter, refraktometer, $\mathrm{pH}$ papper, thermometer, dan spektofotometer. Variabel yang diukur adalah tingkkat keasaman $(\mathrm{pH})$ air, salinitas, dan oksigen terlarut atau dissolved oxygen/DO $(\mathrm{mg} / \mathrm{l})$ dan suhu $\left({ }^{\circ} \mathrm{C}\right)$. Sedangkan variabel yang diukur tiap sehari dua kali adalah nitrat, nitrit, dan ammonia yang dilakukan dengan menggunakan reagen di dalam laboratorium.

\section{Analisis Data}

Rancangan penelitian yang digunakan adalah Rancangan Acak Lengkap (RAL), data yang didapat meliputi data RGR, dan SR yang kemudian data diuji dengan keragaman normalitas, homogenitas dan aditifitas, selanjutnya data tersebut akan dianalisis secara statistik menggunakan analisis ragam atau uji $\mathrm{F}$ untuk mengetahui pengaruh dari perlakuan yang telah dilakukan. Bila perlakuan berpengaruh nyata, selanjutnya diuji dengan uji Wilayah Ganda Duncan untuk mengetahui perbedaan antar nilai tengah dan untuk menentukan mana perlakuan yang terbaik (Hartati et al., 2013).

\section{HASIL}

Hasil analisis ragam menunjukkan jarak tanam rumput laut yang berbeda berpengaruh sangat nyata $(\mathrm{P}<0,01)$ pada pertumbuhan relatif (RGR) rumput laut. Berdasarkan penelitian yang telah dilakukan maka nilai Laju Pertumbuhan Relatif (RGR) dapat dilihat pada Tabel 1.

Tabel 1. Nilai RGR selama penelitian

\begin{tabular}{cc}
\hline \multirow{2}{*}{ Perlakuan } & Variabel yang diamati \\
\cline { 2 - 2 } & RGR RL $(\% /$ hari $)$ \\
\hline A & $0.54 \pm 0.06^{\mathrm{c}}$ \\
$\mathrm{C}$ & $0.64 \pm 0.04^{\mathrm{b}}$ \\
$\mathrm{C}$ & $0.25 \pm 0.02^{\mathrm{b}}$ \\
\hline
\end{tabular}

Keterangan :

Nilai rerata dengan superscript huruf yang berbeda menurut uji duncan

\section{Kualitas air}

Kualitas air merupakan parameter terpenting juga dalam kegiatan budidaya. Parameter kualitas air yang diukur diantaranya suhu, salinitas, $\mathrm{pH}$. Hasil pengukuran parameter kualitas air pada media pemeliharaan rumput laut (Sargassum sp.) selama pemeliharaan tersaji pada Tabel 2.

Tabel 2. Hasil Pengukuran Parameter Kualitas Air pada Media Pemeliharaan Rumput Laut(Sargassum sp.) Selama Penelitian

\begin{tabular}{ccc}
\hline Kualitas Air & Pengukuran & Kelayakan \\
\hline Suhu $\left({ }^{\circ} \mathrm{C}\right)$ & $25-34,1$ & $27,5-29,30^{\mathrm{a}}$ \\
$\mathrm{pH}$ & $7,12-8,20$ & $6,5-8,0^{\mathrm{b}}$ \\
Salinitas $(\mathrm{ppm})$ & $10-21$ & $32-33,5^{\mathrm{a}}$ \\
\hline
\end{tabular}

Keterangan: ${ }^{a} L u t f i a w a n$ et al. (2015), Boedi et al. (2014)

Hasil pengukuran kualitas air menunjukkan bahwa nilai kualitas air selama penelitian masih dalam kisaran nilai kurang layak untuk salinitas menurut pustaka rumput laut Sargassum sp.

\section{PEMBAHASAN}

\section{Laju pertumbuhan relatif Sargassum sp.}

Berdasarkan hasil analisis ragam menunjukkan bahwa jarak tanam yang berbeda berpengaruh nyata $(\mathrm{P}<0,05)$ terhadap laju pertumbuhan relatif Sargassum sp, Laju pertumbuhan relatif pada perlakuan D (jarak tanam $33 \mathrm{~cm}$ ) mempunyai pertumbuhan lebih baik dibandingkan perlakuan C (jarak tanam $28 \mathrm{~cm}$ ) dan B (jarak tanam $23 \mathrm{~cm}$ ) dengan hasil masing-masing tiap perlakuan yaitu $\mathrm{D}(0,82 \pm 0,12), \mathrm{C}(0,64 \pm 0.04)$, dan $\mathrm{B}(0,54 \pm 0.06)$. Perbedaan pertumbuhan diduga karena perbedaan jarak tanam menyebabkan pergerakan air yang lebih luas dalam membawa unsur hara sehingga menyebabkan pertumbuhan rumput laut semakin meningkat, serta karena penempatan rumput laut di permukaan perairan yang menyebabkan penyerapan matahari lebih baik untuk fotosistesis dan selanjutnya untuk proses 
metabolisme. Menurut Prihaningrum et al. (2001) dalam Aditia dan Ilham (2015), menyatakan pertumbuhan rumput laut sangat dipengaruhi oleh jarak ikat yang berhubungan dengan satuan luas lahan, dimana semakin lebar jarak tanam maka semakin luas lintas pergerakan air. Pongarrang et al. (2013), jarak yang semakin lebar memerikan keleluasaan air untuk bergerak dalam mendistribusikan unsur hara pada rumput laut. Sunaryo et al. (2015), berpendapat bahwa perlakuan dengan menempatkan rumput laut di permukaan perairan bisa mencapai laju pertumbuhan lebih tinggi dibandingkan dengan yang lain, dikarenakan perlakuan metode rumput laut pada permukaan perairan lebih efektif dalam menyerap cahaya matahari yang digunakan untuk fotosintesis kemudian selanjutnya untuk proses metabolisme sebagai cadangan makanan rumput laut.

Laju pertumbuhan relatif rumput laut Sargassum sp. yang berbeda nyata namun tidak terlalu jauh perbedaannya pada pertumbuhan rumput laut diduga juga disebabkan oleh kualitas air seperti salinitas yang kurang optimum untuk pertumbuhan rumput laut. Rumput laut dapat tumbuh dengan optimum pada air yang bergerak. Sedangkan pada tambak tempat penelitian air tidak banyak bergerak kecuali dipengaruhi oleh angin. Air yang bergerak dapat berfungsi membersihkan tanaman, menyediakan nutrisi baru. Menurut Parenregi et al. (2012), pergerakan air yang baik dapat meningkatkan pertumbuhan rumput laut, hal itu dikarenakan pergerakan air dapat berfungsi untuk membersihkan rumput laut, menghadirkan nutrisi baru, dan merangsang pertumbuhan rumput laut melalui gaya/tekanan hidrolik gerakan air.

Laju pertumbuhan relatif tertinggi diperoleh pada jarak tanam $33 \mathrm{~cm}$, hal ini diduga karena pada jarak tanam tersebut tidak terjadi persaingan dalam mendapatkan nutrien sehingga nutrien yang ada dapat meningkatkan pertumbuhan rumput laut Sargassum sp. Selain itu diduga karena cahaya matahari yang diterima oleh rumput laut dapat lebih optimal sehingga proses fotosintesis dapat dengan baik sehingga meningkatkan pertumbuhan rumput laut Sargassum sp. Pernyataan ini sesuai dengan Hayashi et al. (2007), cahaya matahari yang cukup baik diterima dapat menentukan kecepatan rumput laut untuk memenuhi kebutuhan nutrien seperti N (nitrogen), C (karbon), dan P (fosfor) yang betujuan untuk pertumbuhan.

Rendahnya pertumbuhan laju pertumbuhan relatif Sargassum sp. pada jarak tanam $23 \mathrm{~cm}$ diduga karena jarak thallus rumput laut yang terlalu dekat menyebabkan terjadinya persaingan dalam mendapatkan unsur hara yang semakin tinggi dan penyerapan unsur hara yang lebih sedikit. Selain itu, adanya kotoran yang menempel pada thallus rumput laut sehingga menghambat proses fotosintesis. Menurut Hermawan (2015), penurunan pertumbuhan dapat diakibatkan karena adanya kotoran pada thallus rumput laut yang menyebabkan terhambatnya penetrasi cahaya yang dibutuhkan untuk proses fotosintesis.

\section{Kualitas Air}

Kualitas air yang telah diamati selama 28 hari pemeliharaan rumput laut diperoleh hasil suhu perairan yang fluktuatif. Suhu perairan tambak pada masa pemeliharaan berkisar antara $25-34,1^{\circ} \mathrm{C}$. Hal ini diduga terjadi karena pada saat masa pemeliharaan kondisi lingkungan mengalami perubahan. Menurut Muarif (2016), suhu perairan tidak bersifat konstan, akan tetapi karakteristiknya menunjukkan perubahan yang dinamis. Suhu akan mempengaruhi berbagai proses fisika dan kimia di perairan seperti densitas air, kelarutan gas, kelarutan senyawa, dan sifat senyawa beracun. Widyartini et al. (2017), suhu yang baik untuk tumbuh Sargassum sp. berkisar antara $25-35^{\circ} \mathrm{C}$.

Nilai $\mathrm{pH}$ yang diperoleh yaitu 7,12-8,20 yang tergolong sesuai untuk pertumbuhan. Menurut Boedi et al. (2014), nilai $\mathrm{pH}$ air yang sesuai untuk rumput laut berkisar antara 6-9. Boyd (2015), $\mathrm{pH}$ dipengaruhi oleh kapasitas penyangga (buffer) yaitu adanya garam-garam karbonat dan bikarbonat yang terkandung didalamnya.

Nilai salinitas yang diperoleh pada saat penelitian yaitu 10-21 ppm, nilai salinitas rendah disebabkan oleh air hujan dan hasil dari variabel tersebut tidak berada dalam kondisi yang layak untuk budidaya rumput laut Sargassum sp. Menurut Widyartini et al. (2017), salinitas yang sesuai untuk budidaya rumput laut Sargassum sp. berada pada kisaran 32-33,5 ppt.

\section{KESIMPULAN DAN SARAN Kesimpulan}

Kesimpulan yang dapat diambil dari hasil penelitian adalah sebagai berikut:

1. Jarak tanam tumput laut Sargassum sp. memberikan pengaruh yang sangat nyata $(\mathrm{P}<0,01)$ terhadap RGR rumput laut Sargassum sp.; dan

2. Perlakuan terbaik pada jarak tanam rumput laut $33 \mathrm{~cm}$ sebesar $0,82 \pm 0,12 \% /$ hari.

\section{Saran}

Saran yang dapat diberikan pada penelitian ini adalah berikut, sebaiknya salinitas yang digunakan seusai dengan rumput laut Sargassum sp. supaya dapat optimal dalam pertumbuhan rumput laut Sargassum sp. 


\section{UCAPAN TERIMA KASIH}

Terima kasih penulis ucapkan kepada Kepala dan Karyawan dari Balai Perbenihan Ikan Air Payau dan Laut Karanganyar, Kecamatan Tugu Kota Semarang yang telah membantu dalam perijinan dan pelaksanaan penelitian, serta semua pihak yang telah mendukung saya untuk dapat melakukan penelitian dan membantu kelancaran dalam penelitian ini.

\section{DAFTAR PUSTAKA}

Aditia, F. dan Ilham. 2015. Budidaya Rumput Laut Sargassum sp. dengan Menggunakan Metode Lepas Dasar dengan Jarak Tanam yang Berbeda. Bul. Tek. Lit. Akuakultur. 13(2): 137-142.

Boedi, S, Juliati, dan Badrudin. 2014. Gracilaria Seaweed Cultivation In Pond. Fishery WWF-Indonesia. Jakarta. 20 pages.

Boyd CE. 2015. Water Quality in Ponds for Aquaculture. Switzerland: Springer. 452p.

Hartati, A., T. Wuryandari., Y. Wilandari. 2013. Analisis Varian Dua Faktor dalam Rancangan Pengamatan Berulang (Repeated Measures). Jurnal Guassian. 2(4): 279-288.

Hayashi, L., N. S. Yokoya., S. Ostini., R. T. L. Pereira., E. S. Braga., E. C. Oliviera. 2008. Nutrients Removed by Kappaphycus alvarezii in Intregrated Culvivation with Fish in Re-Circulating Water. Aquaculture. 277: 185191.

Herliany, N. E., Zamdial., R. Meylla. 2016. Culvation of Seaweed Gracilla sp. Using Longline Methods Under Different Space of Planting. Journal of Aquatropica Asia. 2(2): 11-16. ISSN: 27043601.

Hermawan, D. 2015. Pengaruh Perbedaan Strain Rumput Laut Kappaphcyus alvarezii terhadap Laju Pertumbuhan Spesifik. Jurnal Perikanan dan Kelautan. 5(1): 71-78.

Kementrian Kelautan dan Perikanan. 2018. Produktifitas Perikanan Indonesia pada Forum Merdeka Barat 9 Kementrian Komunikasi dan Informatika. 1-49.

Kusumaningrum, I., B. H. Rini., H. Sri. 2007. Pengaruh Perasan Sargassum crassifolium dengan Konsentrasi yang Berbeda terhadap Pertumbuhan Tanaman Kedelai (Glycine max (L) Merril. 15(2).

Lutfiawan, M., Karman., dan L. Japa. 2015. Analisis Pertumbuhan Sargassum sp. dengan Sistem Budidaya yang Berbeda di Teluk Ekas Lombok Timur. Jurnal Biologi Tropis. 15(2): 129-138.

Muarif. 2016. Karakteristik Suhu Perairan di Kolam Budidaya Perikanan. Jurnal Mina Sains. 2(2): 96-101. ISSN: 24079030.

Muslimin., dan W. W. K. P. Sari. 2017. Budidaya Rumput Laut Sargassum Sp. Dengan Metode Kantong Pada Beberapa Tingkat Kedalaman di Dua Wilayah Perairan Berbeda. Jurnal Riset Akuakultur. 12(3): 221-230. e-ISSN 25026534.

Parenregi, A., R. Syah., E. Suryanti. 2012. Budidaya Rumput Laut Penghasil Karagenan (Karagenofit). Badan Penelitian dan Pengembangan Kelautan Perikanan Republik Indonesia. 1-54hal. ISBN: 978-979-3692-21-0.

Pongarrang, D., A. Rahman dan W. Iba. 2013. Pengaruh Jarak Tanam dan Bobot Bibit Terhadap Pertumbuhan Rumput Laut (Kappaphycus alvarezii) Menggunakan Metode Vertikultur. Jurnal Mina Laut Indonesia 03(12): 94-112.

Sunaryo., R. Ario., dan M. Fachrul. 2015. Studi Tentang Perbedaan Metode Budidaya terhadap Pertumbuhan Rumput Laut Caluerpa sp. Jurnal Kelautan Tropis. 18(1): 13-19.

Takeuchi, T. 1988. Laboratory Work-chemical Evaluation of Dietary Nutriens. In: Watanabe, T. Edo, Fish Nutrition and Mariculture, JICA, Tokyo Univ, Fish. pp. $179-229$.

Widyartini. D. S., P. Widodo., dan A. B. Susanto. 2017. Thallus Variation of Sargassum polycystum from Central Java, Indonesia. Biodiversitas. 18(3): 1004-1011. 